\title{
Kandungan Antosianin dan Karotenoid serta Komponen Produksi pada Berbagai Genotipe Kacang Panjang Berpolong Ungu dan Hijau
}

\section{Anthocyanin and Carotenoid Contents, and Yield Components in Various Genotypes of Purple and Green Yard Long Beans}

\author{
Helvi Ardana Reswari ${ }^{1}$, Muhamad Syukur ${ }^{*}$, dan Willy Bayuardi Suwarno ${ }^{2}$ \\ 'Program Studi Pemuliaan dan Bioteknologi Tanaman, Sekolah Pascasarjana, Institut Pertanian Bogor \\ ${ }^{2}$ Departemen Agronomi dan Hortikultura, Fakultas Pertanian, Institut Pertanian Bogor \\ (Bogor Agricultural University), Jl. Meranti, Kampus IPB Darmaga, Bogor 16680, Indonesia
}

Diterima 28 September 2018/Disetujui 15 Januari 2019

\begin{abstract}
Breeding improved yardlong bean varieties is not only aimed for yield, but also for enhancing nutritional content such as anthocyanin and carotenoids concentrations. The objectives of this research were to elucidate the anthocyanin and carotenoids concentrations as well as yield components in several yard long bean genotypes. This research was conducted at the Leuwikopo Experimental Station and Post Harvest Laboratory of Department of Agronomy and Horticulture IPB from November 2017 to January 2018. The experiment was arranged in a single-factor randomized complete block design with 4 replicates, involving 15 yardlong bean genotypes. The results showed that Fagiola 2 had relatively high anthocyanin and carotenoids contents. Peleton had higher yield than Kinaya 1, Pangeran Anvi, Parade, and Fagiola 2. Anthocyanin content was not correlated with yield components, whereas carotenoids content was positively correlated with the length of pod stalks, length of pods, weight per pod, chlorophyll $a$, chlorophyll b, and total chlorophyll. Pod weights per plant were positively correlated with the number of pods per plant $(r=0.81, P<0.01)$, and can be predicted by a linear model involving number of pods per plant and days to harvest $\left(R^{2}=0.75, P<0.01\right)$.
\end{abstract}

Keywords: biofortification, chlorophyll, correlation, stepwise regression, Vigna unguiculata var. sesquipedalis

\section{ABSTRAK}

Program pemuliaan varietas kacang panjang tidak hanya untuk tujuan peningkatan produksi tetapi juga kandungan nutrisi seperti antosianin dan karotenoid yang tinggi. Penelitian ini bertujuan untuk mengetahui kandungan antosianin, karotenoid dan komponen produksi pada beberapa genotipe kacang panjang. Penelitian dilakukan di Kebun Percobaan Leuwikopo dan Laboratorium Pasca Panen Departemen Agronomi dan Hortikultura IPB pada November 2017 sampai dengan Januari 2018. Percobaan disusun dalam rancangan kelompok lengkap teracak (RKLT) dengan faktor tunggal terdiri atas 15 genotipe dan 4 ulangan. Hasil penelitian menunjukkan bahwa Fagiola 2 memiliki kandungan antosianin dan karotenoid yang relatif tinggi. Produktivitas genotipe Peleton nyata lebih tinggi dibandingkan dengan Kinaya 1, Pangeran Anvi, Parade, dan Fagiola 2. Kandungan antosianin tidak berkorelasi dengan komponen produksi, sedangkan kandungan karotenoid berkorelasi positif dengan panjang tangkai polong, panjang polong, bobot per polong, klorofil a, klorofil b, dan total klorofil. Bobot polong per tanaman berkorelasi positif dengan jumlah polong per tanaman $(r=0.81, P<0.01)$, dan dapat diduga oleh model linier yang berisi jumlah polong per tanaman dan umur panen $\left(R^{2}=0.75, P<0.01\right)$.

Kata kunci: biofortifikasi, klorofil, korelasi, regresi stepwise, Vigna unguiculata var. sesquipedalis

\section{PENDAHULUAN}

Tanaman kacang panjang merupakan salah satu tanaman sayuran penting di Indonesia. Tanaman ini mudah ditanam dan dapat tumbuh baik di dataran rendah maupun

\footnotetext{
* Penulis untuk korespondensi. e-mail: muhsyukur@yahoo.com
}

di dataran tinggi. Hampir seluruh masyarakat Indonesia mengkonsumsi kacang panjang karena sumber protein, asam amino (lisin dan triptofan), dan mineral, selain itu kacang panjang juga banyak dikonsumsi sebagai sayuran maupun pakan ternak (Quaye et al., 2009). Hal ini menyebabkan peningkatan kandungan gizi kacang panjang (biofortifikasi) menjadi penting dilakukan. Biofortifikasi sangat baik dilakukan pada tanaman-tanaman yang sering dikonsumsi 
oleh masyarakat agar dapat efektif dalam meningkatkan kesehatan masyarakat. Peningkatan kandungan provitamin A pada tanaman padi telah dilakukan pada tahun 1990 (Dubock, 2014). Biofortifikasi juga telah dilakukan pada tanaman jagung (Safawo et al., 2010; Rios et al., 2014) tomat (Kiferle et al., 2014) ubi kayu, ubi jalar dan wortel (Junior et al., 2017).

Peningkatan kandungan antosianin dan karotenoid merupakan biofortifikasi yang sering dilakukan saat ini. Antosianin merupakan senyawa organik dari kelompok flavonoid yang merupakan antioksidan yang bermanfaat bagi kesehatan manusia terutama dalam menangkal radikal bebas. Harborne (1987) menyatakan bahwa semua antosianin merupakan struktur turunan dari sianidin baik dengan penambahan dan pengurangan gugus hidroksil, atau metilasi. Karotenoid bagi kesehatan berfungsi sebagai penangkal radikal bebas (Qudah, 2014). Karotenoid telah dikembangkan sebagai efek protektif melawan sel kanker, penyakit jantung, mengurangi penyakit mata, antioksidan, dan regulator dalam sistem imun tubuh (Kurniawan et al., 2010).

Selain peningkatan gizi pada tanaman kacang panjang, terus menurunnya produktivitas kacang panjang juga menjadi tantangan saat ini. Produksi kacang panjang menurun dari 455.615 ton pada tahun 2012 menjadi hanya 388.071 ton pada tahun 2016 (BPS, 2017). Peningkatan produtivitas bisa menjadi salah satu solusi dari tantangan tersebut. Oleh karena itu, penting untuk dihasilkan varietas kacang panjang dengan produktivitas yang tinggi dan kandungan gizi yang lebih baik.

Kacang panjang dengan kandungan antosianin tinggi sudah dilaporkan pada beberapa penelitian namun belum dibudidayakan secara komersial. Kuswanto et al. (2013) menyatakan terdapat 15 kandidat varietas kacang panjang berpolong ungu tetapi masih perlu dilakukan uji adaptasi dan daya hasil sehingga belum ada varietas kacang panjang dengan produktivitas tinggi dan kandungan gizi yang baik. Hal ini diduga karena masih belum banyak informasi tentang keragaman genetik serta informasi tentang hubungan antar karakter komponen hasil, hasil dan karakter terkait gizi pada tanaman kacang panjang di Indonesia. Penelitian ini bertujuan untuk mengetahui kandungan antosianin, karotenoid dan komponen produksi serta korelasinya pada berbagai genotipe kacang panjang.

\section{BAHAN DAN METODE}

PenelitianinidilakukandiKebunPercobaanLeuwikopo IPB dan Laboratorium Pasca Panen Departemen Agronomi dan Hortikultura IPB pada November 2017 sampai dengan Januari 2018. Bahan tanaman yang digunakan adalah 15 genotipe yang mewakili kacang panjang berpolong ungu dan kacang panjang berpolong hijau. Genotipe kacang panjang berpolong ungu yaitu Fagiola 1, Fagiola 2, sedangkan kacang panjang berpolong hijau yaitu Kinaya 1, Kinaya 2, Parade, Borneo, Pangeran Anvi, Kanton Tavi, Peleton, Pertiwi, Tong-tong, Wulung, Sabrina, Leuwikopo, dan Cilibende.
Penanaman menggunakan jarak tanam $50 \mathrm{~cm} \times 50$ $\mathrm{cm}$, dengan sistem tanam dua baris tanaman dalam satu bedengan (double row). Ukuran bedengan $5 \mathrm{~m} \mathrm{x} 1 \mathrm{~m}$. Setiap bedengan ditutup dengan mulsa plastik hitam perak (MPHP). Percobaan disusun dalam rancangan kelompok lengkap teracak (RKLT) satu faktor yaitu genotipe dengan 4 ulangan. Masing-masing genotipe per ulangan ditanam sebanyak 20 tanaman.

Pemupukan dilaksanakan setiap satu minggu sekali dengan menggunakan larutan NPK (16:16:16) dengan konsentrasi $10 \mathrm{~g} \mathrm{~L}^{-1}$ dan pupuk daun $5 \mathrm{~g} \mathrm{~L}^{-1}$, setiap tanaman diberi $250 \mathrm{ml}$ larutan pupuk per lubang setiap pemupukan. Pengendalian hama dan penyakit dilakukan setiap satu minggu sekali menggunakan Curacron dengan konsentrasi $1.5 \mathrm{~g} \mathrm{~L}^{-1}$ dan Antracol $1.5 \mathrm{~g} \mathrm{~L}^{-1}$. Pengendalian gulma dilaksanakan secara manual. Karakter komponen produksi yang diamati terdiri atas panjang tangkai polong $(\mathrm{cm})$, panjang polong $(\mathrm{cm})$, diameter polong $(\mathrm{cm})$, bobot per polong $(\mathrm{g})$, jumlah polong per tanaman, bobot polong per tanaman (g) dan umur panen (HST). Pengamatan kandungan antosianin $\left(\mathrm{mg} \mathrm{g}^{-1}\right)$, karotenoid $\left(\mathrm{mg} \mathrm{g}^{-1}\right)$, klorofil a $\left(\mathrm{mg} \mathrm{g}^{-1}\right)$, klorofl $\mathrm{b}\left(\mathrm{mg} \mathrm{g}^{-1}\right)$, dan klorofil total $\left(\mathrm{mg} \mathrm{g}^{-1}\right)$ dilakukan dengan metode spektrofotometri (Sims dan Gamon, 2002).

Analisis ragam dilakukan dengan perangkat lunak SAS 9.0. Apabila pengaruh genotipe nyata pada taraf 5\% maka dilanjutkan dengan uji perbedaan nilai tengah dengan metode DMRT (Duncan's multiple range test). Analisis korelasi dilakukan untuk mengetahui hubungan antar karakter, selanjutnya regresi linier berganda metode stepwise regression dilakukan untuk mengetahui karakter yang paling berpengaruh terhadap antosianin, karotenoid dan produksi. Analisis korelasi dan regresi linier berganda dengan metode stepwise regression dilakukan menggunakan perangkat lunak STAR (Statistical Tool for Agricultural Research).

\section{HASIL DAN PEMBAHASAN}

\section{Kandungan Antosianin, Karotenoid dan Klorofil}

Pigmen antosianin umumnya ditemukan pada buah dan sayur yang berwarna ungu, merah atau biru. Kandungan antosianin pada genotipe Fagiola 1 dan Fagiola 2 lebih tinggi dibandingkan dengan genotipe lainnya. Genotipe Fagiola 1 dan Fagiola 2 merupakan genotipe kacang panjang yang berpolong ungu sehingga memiliki kandungan antosianin yang tinggi. Hal ini menguatkan hasil penelitian Cahyaningrum et al. (2014) yang melaporkan bahwa galur kacang panjang UBPU2 222 yang memiliki batang dan polong berwarna ungu dengan tingkat keunguan yang paling pekat (deep purplish red 35 B) juga memiliki kandungan antosianin tinggi yaitu $189.54 \mathrm{ppm}$.

Hasil analisis kandungan karotenoid menunjukkan bahwa genotipe Borneo, Wulung, Fagiola 2, dan Sabrina memiliki kandungan karotenoid yang lebih tinggi dibandingkan genotipe lainnya. Genotipe Cilibende memiliki kandungan karotenoid yang paling rendah. Berdasarkan hasil analisis ini pada genotipe yang mempunyai kandungan klorofil tinggi juga mempunyai kandungan karotenoid yang 
tinggi. Selain memiliki kandungan klorofil yang tinggi, genotipe Fagiola 2 juga memiliki kandungan antosianin dan karotenoid yang tinggi (Tabel 1). Hal ini dikarenakan genotipe Fagiola 2 mempunyai polong yang berwarna ungu tua dengan garis tengah yang berwarna hijau tua. Menurut Kurniawan et al. (2010) karotenoid berperan sebagai pigmen tambahan yang membantu klorofil dalam menyerap cahaya. Selain itu Fabrowska et al. (2018) menyatakan bahwa klorofil dan karotenoid merupakan pigmen penting pada fotosintesis yang mempunyai fungsi saling melengkapi dalam menyerap cahaya.

Hasil analisis ragam menunjukkan bahwa klorofil a, klorofil b, dan total klorofil pada genotipe Borneo, Wulung, dan Fagiola 2 berbeda nyata dengan genotipe Cilibende tetapi tidak berbeda nyata dengan 11 genotipe yang lain (Tabel 1). Klorofil merupakan pigmen yang berwarna hijau sehingga pada kacang panjang yang berwarna hijau akan memiliki kandungan klorofil yang tinggi seperti pada genotipe Borneo, Wulung dan Fagiola 2 sedangkan genotipe Cilibende memiliki warna polong putih kehijauan.

Antosianin memiliki manfaat penting sebagai penangkal radikal bebas. Selain itu, antosianin juga dapat menghambat pertumbuhan sel tumor atau antikarsinogenik, dan mencegah diabetes (Subuluntika dan Ayustaningwarno, 2013). Pendapat lain menyatakan bahwa antosianin dapat digunakan sebagai agen proteksi dari berbagai patogen berbahaya dan attractant serangga pada polinasi (Pervaiz et al., 2017). Karotenoid memiliki fungsi melindungi klorofil dari efek cahaya yang berlebih. Karotenoid dapat membantu meningkatkan sistem imun dan mencegah kanker (Limantara dan Indriatmoko, 2012). Klorofil merupakan pigmen yang dibutuhkan dalam reaksi fotosintesis pada tanaman. Karotenoid dan klorofil berperan penting dalam mencegah berbagai penyakit yang berkaitan dengan stress oksidatif seperti kanker, penyakit kardiovaskular, dan berbagai penyakit kronis lainnya (Sangeetha dan Baskaran, 2010).

\section{Komponen Produksi}

Karakter panjang polong terpanjang dihasilkan oleh genotipe Peleton namun tidak berbeda nyata dengan genotipe Kinaya 2, Pertiwi, dan Tong-tong sedangkan panjang polong terpendek dihasilkan oleh genotipe Cilibende (Tabel 2). Bobot per polong menunjukkan perbedaan pada setiap genotipe yang diamati. Kinaya 2 merupakan genotipe yang memiliki bobot per polong tertinggi namun tidak berbeda nyata dengan Fagiola 2, Sabrina, dan Wulung. Bobot per polong paling rendah dihasilkan oleh genotipe Cilibende.

Umur panen genotipe Fagiola 2 lebih pendek dibandingkan genotipe Sabrina dan Wulung namun tidak berbeda nyata dengan genotipe Cilibende, Leuwikopo, dan Peleton. Jumlah polong per tanaman paling banyak dihasilkan oleh genotipe Cilibende dibandingkan dengan genotipe lainnya. Genotipe Peleton memiliki bobot polong per tanaman lebih tinggi dibandingkan dengan genotipe Fagiola 2, Kinaya 1, Pangeran Anvi, dan Parade; tetapi tidak berbeda nyata dengan genotipe lainnya. Genotipe Peleton

Tabel 1. Rata-rata kandungan klorofil, antosianin dan karotenoid beberapa genotipe kacang panjang

\begin{tabular}{llllll}
\hline Genotipe & $\begin{array}{c}\text { Klorofil a } \\
\left(\mathrm{mg} \mathrm{g}^{-1}\right)\end{array}$ & $\begin{array}{c}\text { Klorofil b } \\
\left(\mathrm{mg} \mathrm{g}^{-1}\right)\end{array}$ & $\begin{array}{c}\text { Total klorofil } \\
\left(\mathrm{mg} \mathrm{g}^{-1}\right)\end{array}$ & $\begin{array}{c}\text { Antosianin } \\
\left(\mathrm{mg} \mathrm{g}^{-1}\right)\end{array}$ & $\begin{array}{c}\text { Karotenoid } \\
\left(\mathrm{mg} \mathrm{g}^{-1}\right)\end{array}$ \\
\hline Borneo & $0.034 \mathrm{a}$ & $0.026 \mathrm{a}$ & $0.060 \mathrm{a}$ & $0.008 \mathrm{bcd}$ & $0.014 \mathrm{a}$ \\
Cilibende & $0.004 \mathrm{e}$ & $0.004 \mathrm{e}$ & $0.008 \mathrm{f}$ & $0.006 \mathrm{~cd}$ & $0.002 \mathrm{f}$ \\
Fagiola 1 & $0.015 \mathrm{bcde}$ & $0.010 \mathrm{cde}$ & $0.025 \mathrm{cdef}$ & $0.017 \mathrm{a}$ & $0.006 \mathrm{bcdef}$ \\
Fagiola 2 & $0.033 \mathrm{a}$ & $0.024 \mathrm{ab}$ & $0.058 \mathrm{a}$ & $0.014 \mathrm{ab}$ & $0.013 \mathrm{a}$ \\
Kanton Tavi & $0.024 \mathrm{abcd}$ & $0.022 \mathrm{ab}$ & $0.046 \mathrm{abc}$ & $0.008 \mathrm{bcd}$ & $0.011 \mathrm{abc}$ \\
Kinaya 1 & $0.008 \mathrm{de}$ & $0.009 \mathrm{de}$ & $0.016 \mathrm{ef}$ & $0.007 \mathrm{bcd}$ & $0.004 \mathrm{ef}$ \\
Kinaya 2 & $0.020 \mathrm{abcde}$ & $0.017 \mathrm{abcd}$ & $0.038 \mathrm{abcde}$ & $0.007 \mathrm{bcd}$ & $0.009 \mathrm{abcde}$ \\
Leuwikopo & $0.011 \mathrm{cde}$ & $0.007 \mathrm{de}$ & $0.018 \mathrm{def}$ & $0.002 \mathrm{~d}$ & $0.004 \mathrm{def}$ \\
Pangeran Anvi & $0.022 \mathrm{abcd}$ & $0.017 \mathrm{abcd}$ & $0.039 \mathrm{abcde}$ & $0.008 \mathrm{bcd}$ & $0.010 \mathrm{abc}$ \\
Parade & $0.027 \mathrm{abc}$ & $0.021 \mathrm{abc}$ & $0.048 \mathrm{abc}$ & $0.010 \mathrm{abc}$ & $0.011 \mathrm{abc}$ \\
Peleton & $0.016 \mathrm{bcde}$ & $0.013 \mathrm{bcde}$ & $0.029 \mathrm{bcdef}$ & $0.008 \mathrm{bcd}$ & $0.006 \mathrm{cdef}$ \\
Pertiwi & $0.028 \mathrm{abc}$ & $0.023 \mathrm{ab}$ & $0.051 \mathrm{abc}$ & $0.007 \mathrm{bcd}$ & $0.012 \mathrm{ab}$ \\
Sabrina & $0.032 \mathrm{ab}$ & $0.023 \mathrm{ab}$ & $0.055 \mathrm{ab}$ & $0.006 \mathrm{~cd}$ & $0.013 \mathrm{a}$ \\
Tong- tong & $0.025 \mathrm{abc}$ & $0.020 \mathrm{abc}$ & $0.045 \mathrm{abcd}$ & $0.007 \mathrm{bcd}$ & $0.010 \mathrm{abcd}$ \\
Wulung & $0.034 \mathrm{a}$ & $0.026 \mathrm{a}$ & $0.060 \mathrm{a}$ & $0.008 \mathrm{bcd}$ & $0.013 \mathrm{a}$ \\
KK (\%) & 31.36 & 27.18 & 29.07 & 36.13 & 26.66 \\
\hline Ked & & & \\
\hline
\end{tabular}

Keterangan: Angka-angka yang diikuti oleh huruf yang berbeda pada kolom yang sama adalah berbeda nyata pada uji DMRT taraf $\alpha=5 \%$;K $=$ koefisien keragaman 
Tabel 2. Rata-rata komponen produksi beberapa genotipe kacang panjang

\begin{tabular}{|c|c|c|c|c|c|c|c|}
\hline Genotipe & $\begin{array}{l}\text { PTP } \\
(\mathrm{cm})\end{array}$ & $\begin{array}{c}\mathrm{PP} \\
(\mathrm{cm})\end{array}$ & $\begin{array}{c}\mathrm{DP} \\
(\mathrm{cm})\end{array}$ & $\begin{array}{l}\text { BP } \\
(\mathrm{g})\end{array}$ & $\begin{array}{c}\text { UP } \\
(\mathrm{HST})\end{array}$ & JPT & $\begin{array}{c}\text { BPT } \\
(\mathrm{g})\end{array}$ \\
\hline Borneo & $34.12 \mathrm{ab}$ & $50.73 \mathrm{ef}$ & $0.60 \mathrm{ab}$ & $13.58 \mathrm{bcd}$ & $48.5 \mathrm{abcd}$ & $14.5 b c$ & $243.77 \mathrm{ab}$ \\
\hline Cilibende & $21.36 \mathrm{f}$ & $39.95 \mathrm{~h}$ & $0.60 \mathrm{ab}$ & $7.94 \mathrm{e}$ & 41.5hi & $24.8 \mathrm{a}$ & $209.98 \mathrm{abc}$ \\
\hline Fagiola 1 & $28.33 \mathrm{~cd}$ & $47.99 f$ & $0.60 \mathrm{ab}$ & $12.19 \mathrm{~cd}$ & 44.2efgh & $18.4 b$ & $198.79 \mathrm{abc}$ \\
\hline Fagiola 2 & $29.62 b c$ & $52.55 \mathrm{cde}$ & $0.62 \mathrm{a}$ & $14.75 \mathrm{abc}$ & $40.0 \mathrm{i}$ & $14.5 b c$ & $160.08 \mathrm{c}$ \\
\hline Kanton Tavi & $27.12 \mathrm{cde}$ & $53.25 \mathrm{bcde}$ & $0.60 \mathrm{ab}$ & $13.79 \mathrm{bcd}$ & $46.0 \mathrm{cdef}$ & $15.2 b c$ & $265.64 \mathrm{ab}$ \\
\hline Kinaya 1 & $24.03 \mathrm{def}$ & $50.02 \mathrm{ef}$ & $0.61 \mathrm{ab}$ & $13.90 \mathrm{bc}$ & $49.3 \mathrm{abc}$ & $13.6 b c$ & $196.45 b c$ \\
\hline Kinaya 2 & $29.63 b c$ & $57.05 \mathrm{ab}$ & $0.60 \mathrm{ab}$ & $16.87 \mathrm{a}$ & $49.5 \mathrm{ab}$ & $12.9 \mathrm{bc}$ & $242.62 \mathrm{ab}$ \\
\hline Leuwikopo & $22.78 \mathrm{ef}$ & $43.79 \mathrm{~g}$ & $0.63 a$ & $11.20 \mathrm{~d}$ & 42.0ghi & $16.8 b c$ & $216.09 \mathrm{abc}$ \\
\hline Pangeran Anvi & $34.94 a$ & $50.52 \mathrm{ef}$ & $0.60 \mathrm{ab}$ & $14.02 \mathrm{bc}$ & $46.3 \mathrm{bcde}$ & $13.6 b c$ & $190.63 b c$ \\
\hline Parade & $22.60 \mathrm{ef}$ & $51.55 \mathrm{def}$ & $0.58 b$ & $13.39 \mathrm{bcd}$ & 48.3abcd & $13.5 b c$ & $195.63 b c$ \\
\hline Peleton & $26.52 \mathrm{cdef}$ & $57.75 \mathrm{a}$ & $0.61 \mathrm{ab}$ & $13.67 \mathrm{bcd}$ & 42.8fghi & $16.6 \mathrm{bc}$ & $275.48 \mathrm{a}$ \\
\hline Pertiwi & $28.21 \mathrm{~cd}$ & 55.29abcd & $0.57 \mathrm{~b}$ & $13.76 \mathrm{bcd}$ & $45.3 \mathrm{defg}$ & $13.5 \mathrm{bc}$ & $249.39 \mathrm{ab}$ \\
\hline Sabrina & $30.80 \mathrm{abc}$ & $52.57 \mathrm{cde}$ & $0.60 \mathrm{ab}$ & $14.60 \mathrm{abc}$ & $51.0 \mathrm{a}$ & $13.8 b c$ & $241.91 \mathrm{ab}$ \\
\hline Tong-tong & $22.27 \mathrm{ef}$ & $55.87 \mathrm{abc}$ & $0.63 \mathrm{a}$ & $14.20 b c$ & 43.8efgh & $17.3 b$ & $257.16 \mathrm{ab}$ \\
\hline Wulung & $35.14 \mathrm{a}$ & $53.00 \mathrm{bcde}$ & $0.61 \mathrm{ab}$ & $15.47 \mathrm{ab}$ & $51.0 \mathrm{a}$ & $11.5 \mathrm{c}$ & $201.85 \mathrm{abc}$ \\
\hline KK (\%) & 11.73 & 4.99 & 4.08 & 11.98 & 22.01 & 4.71 & 20.84 \\
\hline
\end{tabular}

Keterangan: Angka-angka yang diikuti oleh huruf yang berbeda pada kolom yang sama adalah berbeda nyata pada uji DMRT taraf $\alpha=$ $5 \%$; $\mathrm{PTP}=$ panjang tangkai polong, $\mathrm{PP}=$ panjang polong, $\mathrm{DP}=$ diameter polong, $\mathrm{BP}=$ bobot per polong, $\mathrm{UP}=$ umur panen, $\mathrm{JPT}=$ jumlah polong per tanaman, $\mathrm{BPT}=$ bobot polong per tanaman; $\mathrm{KK}=$ koefisien keragaman

memiliki bobot polong per tanaman lebih tinggi antara lain karena ukuran polongnya panjang. Menurut Cahyaningrum et al. (2014) bobot polong per tanaman dipengaruhi oleh panjang polong.

Genotipe yang memiliki panjang tangkai polong terpanjang adalah genotipe Wulung dan Pangeran Anvi namun tidak berbeda nyata terhadap genotipe Borneo dan Sabrina. Panjang tangkai polong paling pendek dihasilkan oleh genotipe Cilibende tetapi tidak berbeda nyata dengan genotipe Kinaya 1, Leuwikopo, Parade, Peleton, dan Tongtong. Panjang tangkai polong yang pendek berpengaruh terhadap bobot polong per tanaman, sehingga panjang tangkai polong bisa dijadikan salah satu kriteria penting dalam seleksi ke arah peningkatan produksi kacang panjang.

\section{Korelasi antar Karakter}

Analisis korelasi menunjukkan bahwa jumlah polong per tanaman berkorelasi positif terhadap bobot polong per tanaman $(\mathrm{r}=0.81, \mathrm{P}<0.01)$ (Tabel 3). Menurut Diwaker et al. (2018) jumlah polong per tanaman memiliki korelasi genotipik yang nyata dan positif terhadap bobot polong per tanaman yaitu sebesar 0.61 . Hasil penelitian lainnya Almeida et al. (2014) juga menyatakan bahwa komponen hasil yang berpengaruh besar terhadap produktivitas adalah jumlah polong per tanaman. Selain itu Freitas et al. (2016) juga menyatakan bahwa jumlah polong per tanaman memiliki pengaruh langsung yang sangat besar terhadap hasil. Jumlah polong per tanaman berkorelasi negatif terhadap bobot per polong $(\mathrm{R}=-0.87, \mathrm{P}<0.01)$. Hasil ini mengindikasikan bahwa genotipe-genotipe yang memiliki jumlah polong per tanaman yang banyak cenderung memiliki bobot per polong yang rendah. Hal ini sejalan dengan penelitian Kuswanto (2006) bahwa variasi bobot polong kacang panjang sangat dipengaruhi oleh jumlah polong per tanaman. Apabila jumlah polong bertambah banyak sedangkan panjang polong tidak bertambah panjang maka bobot polong per tanaman juga bertambah berat. Hasil penelitian lainnya Das et al. (2018) menyatakan bahwa jumlah polong per tanaman kacang panjang berkorelasi positif dan nyata terhadap produksi per tanaman baik secara genotipik maupun fenotipik. Putri et al. (2017) mengemukakan bahwa tanaman terung yang memiliki jumlah buah per tanaman sedikit cenderung memiliki buah yang lebih berat dan besar karena memperoleh hasil fotosintat yang lebih banyak.

Panjang polong berkorelasi positif terhadap bobot per polong $(\mathrm{r}=0.85, \mathrm{P}<0.01)$. Hal ini mengindikasikan bahwa genotipe-genotipe yang memiliki polong yang panjang cenderung memiliki bobot yang tinggi. Diameter polong tidak menunjukkan adanya korelasi terhadap karakter lain. Bobot per polong berkorelasi positif dengan umur panen $(\mathrm{r}=0.55, \mathrm{P}<0.01)$, dimana genotipe-genotipe yang memiliki umur panen lebih panjang cenderung memiliki bobot per polong yang tinggi.

Kandungan klorofil a berkorelasi positif terhadap klorofil b, karotenoid dan total klorofil, sedangkan klorofil b berkorelasi positif dengan karotenoid dan total klorofil. Hal ini menunjukkan bahwa bertambahnya kandungan klorofil pada kacang panjang diikuti oleh pertambahan 
Reswari et al. / J. Agron. Indonesia 47(1):61-67

Tabel 3. Koefisien nilai korelasi antar karakter beberapa genotipe kacang panjang

\begin{tabular}{|c|c|c|c|c|c|c|c|c|c|c|c|c|}
\hline & PTP & PP & DP & BP & JPT & BPT & UP & KLA & KLB & ANT & KAR & TKL \\
\hline PTP & 1.00 & & & & & & & & & & & \\
\hline PP & 0.32 & 1.00 & & & & & & & & & & \\
\hline DP & -0.16 & -0.12 & 1.00 & & & & & & & & & \\
\hline BP & $0.55^{*}$ & $0.85 * *$ & -0.01 & 1.00 & & & & & & & & \\
\hline JPT & $-0.58 *$ & $-0.65^{* *}$ & 0.19 & $-0.87 * *$ & 1.00 & & & & & & & \\
\hline BPT & -0.41 & -0.48 & -0.10 & $-0.71 * *$ & $0.81 * *$ & 1.00 & & & & & & \\
\hline UP & 0.46 & 0.32 & -0.35 & $0.55^{*}$ & $-0.65^{* *}$ & -0.30 & 1.00 & & & & & \\
\hline KLA & $0.63 *$ & $0.56^{*}$ & -0.18 & $0.64 *$ & $-0.65 * *$ & -0.49 & 0.37 & 1.00 & & & & \\
\hline KLB & $0.60 *$ & $0.63^{*}$ & -0.24 & $0.68 * *$ & $-0.68 * *$ & -0.46 & 0.42 & $0.98 * *$ & 1.00 & & & \\
\hline ANT & 0.22 & 0.13 & -0.16 & 0.14 & -0.01 & -0.32 & -0.16 & 0.22 & 0.17 & 1.00 & & \\
\hline KAR & $0.65^{* *}$ & $0.57^{*}$ & -0.26 & $0.66^{* *}$ & $-0.67 * *$ & -0.48 & 0.41 & $0.99 * *$ & $0.99 * *$ & 0.20 & 1.00 & \\
\hline TKL & $0.62 *$ & $0.59 *$ & -0.20 & $0.66^{* *}$ & $-0.66^{* *}$ & -0.48 & 0.39 & $0.99 * *$ & $0.99 * *$ & 0.20 & $0.99 * *$ & 1.00 \\
\hline
\end{tabular}

Keterangan: $\mathrm{PTP}=$ panjang tangkai polong; $\mathrm{PP}=$ panjang polong; $\mathrm{DP}=$ diameter polong; $\mathrm{BP}=$ bobot per polong; $\mathrm{UP}=\mathrm{umur}$ panen; $\mathrm{JPT}=$ jumlah polong per tanaman; $\mathrm{BPT}=$ bobot polong per tanaman; KLA = klorofil $\mathrm{a} ; \mathrm{KLB}=$ klorofil b; $\mathrm{ANT}=$ antosianin; $\mathrm{KAR}=$ karotenoid; TKL = total klorofil; * = nyata pada taraf $\alpha=5 \%$; ** nyata pada taraf $\alpha=1 \%$.

kandungan karotenoid. Kurniawan et al. (2010) melakukan pengukuran kandungan klorofil dan karotenoid pada tumbuhan akuatik Nymphaea sp. dan mengemukakan bahwa karotenoid berperan sebagai pigmen tambahan pada proses fotosintesis karena karotenoid membantu klorofil dalam penyerapan cahaya. Hasimi et al. (2016) berpendapat bahwa perombakan klorofil akan diikuti pembentukan karotenoid dalam keadaan suhu udara rendah di bawah $13^{\circ} \mathrm{C}$ pada buah jeruk. Suhu udara di lahan percobaan dalam penelitian ini berkisar $25-28{ }^{\circ} \mathrm{C}$, sedangkan sampel kacang panjang yang dianalisis antosianin dan karotenoidnya dipanen segar. Selanjutnya sampel disimpan di dalam cool box yang berisi es batu sehingga memiliki kisaran suhu $0{ }^{\circ} \mathrm{C}$.

\section{Regresi Linear Berganda}

Prediksi besarnya nilai suatu karakter menggunakan beberapa karakter lainnya dapat dilakukan melalui analisis regresi linier berganda. Metode yang digunakan dalam pemilihan peubah bebas (X) pada penelitian ini adalah stepwise regression, yang merupakan kombinasi dari metode pemilihan variabel lainnya yaitu forward selection dan backward elimination (Ghani dan Ahmad, 2010). Penentuan model linier yang sesuai pada stepwise regression ini didasarkan pada nilai AIC (Akaike information criterion), dimana nilai AIC yang paling kecil mengindikasikan kesesuaian model yang paling baik.

Hasil analisis regresi linier berganda (Tabel 4) menunjukkan bahwa karakter karotenoid dan total klorofil dapat diduga dengan panjang tangkai polong dan panjang polong $(\mathrm{P}<0.01)$, meskipun modelnya tidak cukup baik karena nilai koefisien determinasinya hanya sekitar 50\%. Bobot polong per tanaman memiliki hubungan linier dengan jumlah polong per tanaman dan umur panen $(\mathrm{P}<0.01)$, dengan nilai koefisien determinasi yang cukup tinggi yaitu $75 \%$.
Nilai koefisien determinasi menunjukkan besarnya keragaman peubah terikat (Y) yang dapat dijelaskan oleh model (X), sedangkan sisanya tidak dapat dijelaskan oleh model tetapi oleh faktor lainnya. Sebanyak $75 \%$ keragaman bobot polong per tanaman dapat dijelaskan oleh model yang berisi jumlah polong per tanaman dan umur panen, sedangkan $25 \%$ sisanya tidak dapat dijelaskan oleh model. Hannachi et al. (2013) berpendapat bahwa nilai koefisien determinasi menunjukkan keefektifan sifat-sifat (X) dalam suatu model regresi untuk menjelaskan Y.

\section{KESIMPULAN}

Terdapat perbedaan kandungan antosianin dan karotenoid serta komponen produksi pada sejumlah genotipe kacang panjang yang dievaluasi. Genotipe Fagiola 2 memiliki kandungan antosianin dan karotenoid yang relatif tinggi. Produktivitas genotipe Peleton nyata lebih tinggi dibandingkan dengan Kinaya 1, Pangeran Anvi, Parade, dan Fagiola 2. Kandungan antosianin tidak berkorelasi dengan komponen produksi, sedangkan kandungan karotenoid berkorelasi positif dengan panjang tangkai polong, panjang polong, bobot per polong, klorofil a, klorofil $b$, dan total klorofil. Bobot polong per tanaman berkorelasi positif dengan jumlah polong per tanaman $(r=0.81, P<0.01)$, dan dapat diduga oleh model regresi yang berisi jumlah polong per tanaman dan umur panen $\left(\mathrm{R}^{2}=0.75, \mathrm{P}<0.01\right)$.

\section{UCAPAN TERIMAKASIH}

Terima kasih disampaikan kepada Kementerian Riset dan Teknologi yang telah membiayai penelitian ini melalui hibah Insinas tahun 2017-2018 atas nama Prof. Dr. Muhamad Syukur, SP., M.Si. 
Tabel 4. Koefisien regresi linear berganda pada beberapa genotipe kacang panjang

\begin{tabular}{lccc}
\hline Karakter & Nilai $\mathrm{F}$ & $\mathrm{R}^{2}$ terkoreksi & Model \\
\hline Karotenoid & $7.91^{* *}$ & 0.50 & $\mathrm{KAR}=-0.0197+0.0004 \mathrm{PTP}+0.0003 \mathrm{PP}$ \\
Total klorofil & $7.59^{* *}$ & 0.49 & $\mathrm{TKL}=-0.0893+0.0018 \mathrm{PTP}+0.0016 \mathrm{PP}$ \\
Bobot polong per tanaman & $17.60^{* *}$ & 0.75 & $\mathrm{BPT}=-714.97+30.96 \mathrm{JPT}+10.56 \mathrm{UP}$ \\
\hline
\end{tabular}

Keterangan: $\mathrm{PTP}=$ panjang tangkai polong; $\mathrm{PP}=$ panjang polong; $\mathrm{UP}=$ umur panen; JPT $=$ jumlah polong per tanaman; $\mathrm{BPT}=$ bobot polong per tanaman; KAR $=$ karotenoid; TKL $=$ total klorofil; $* *=$ nyata pada taraf $1 \%$

\section{DAFTAR PUSTAKA}

[BPS] Badan Pusat Statistik. 2017. Produksi Tanaman Sayuran. Jakarta: Badan Pusat Statistik. https://www. bps.go.id [15 September 2017].

Almeida, W.S., F.R.B. Fernandes, E.M. Teofilo, C.H.C.M. Bertini. 2014. Correlation and path analysis in components of grain yield of cowpea genotypes. Rev. Cien. Agron. 45:726-736.

Cahyaningrum, D.A., I. Yulianah, Kuswanto. 2014. Interaksi genotipe lingkungan galur-galur harapan kacang panjang (Vigna sesquipedalis L. Fruwirth) berpolong ungu di dua lokasi. J. Produksi Tanaman 2:404-411.

Das, R.R., P. Talukdar, P. Kumar, S.B. Neog. 2018. Relationship among different secondary traits and seed yield in cowpea (Vigna unguiculata L. Walp). Int. J. Curr. Microbiol. App. Sci. 7:1382-1396.

Diwaker, P., M.K. Sharma., A.K. Soni., A. Diwaker., P. Singh. 2018. Character association and path coefficient analysis in vegetable cowpea (Vigna unguiculata L. Walp). J. Pharmac. Phytochem. 7:2289-2293.

Dubock, A. 2014. The Present Status of Golden Rice. J. of Huazhong Agric. Univ. 33:69-84.

Fabrowska, J., B. Messyasz, J. Szyling, J. Walkowiak, B. Leska. 2018. Isolation of chlorophylls and carotenoids from freshwater algae using different extraction methods. Phycol. Res. 66:52-57.

Freitas, T.G.G., P.S.L.E. Silva, J.C. Dovale, E.M.D. Silva. 2016. Green bean yield and path analysis in cowpea landraces. Revista Caatinga Mossorob 29:866-877.

Ghani, I.M.M., S. Ahmad. 2010. Stepwise multiple regression method to forecast fish landing. Procedia Social and Behavioral Sci. 8:549-554.

Hannachi, A., Z.E.A. Fellahi, H. Bouzerzour, A. Boutekrabt. 2013. Correlation, path analysis and stepwise regression in durum wheat (Triticum durum Desf.) under rainfed conditions. J. Agric. Sustainability 3:122-131.
Harborne, J.B. 1987. Metode Fitokimia Penuntun Cara Modern Menganalisis Tumbuhan. Institut Teknologi Bandung.

Hasimi, N.M., R. Poerwanto., K. Suketi. 2016. Degreening buah jeruk siam (Citrus nobilis) pada beberapa konsentrasi dan durasi pemaparan etilen. J. Hort. Indonesia 7:111-120.

Junior, R.M., R.S. Gomes, C.F Almeida, F.M. Alves, F.T. Delazari, R.D.F. Laurindo, R.H. Fernandes, D.J.H. Silva. 2017. Vegetable breeding as a strategy of biofortification in carotenoids and prevention of vitamin A deficiency. Afr. J. Agric. Res. 12:10591066.

Kiferle, C., S. Gonzali, H.T. Holwerda, R.R. Ibaceta, P. Perata. 2014. Tomato fruits: a good target for iodine biofortification. Front. Plant Sci. Plant Physiol. 4:110.

Kurniawan, M., M. Izzati, Y. Nurchayati. 2010. Kandungan klorofil, karotenoid, dan vitamin $\mathrm{C}$ pada beberapa spesies tumbuhan akuatik. Bul. Anatomi Fisiologi 18:28-40.

Kuswanto, B. Waluyo, P. Hardinaningsih. 2013. Segregation and selection of observed yardlong bean (Vigna sesquipedalis L. fruwirth) to get expected lines of purple pod. Int. Res. J. Agric. Sci. Soil Sci. 3:88-92.

Kuswanto. 2006. Keragaman genetik populasi bulk F2, F3 dan F4 kacang panjang hasil persilangan PS X MLG 15151. J. Agrivita 28 (2):109-114.

Limantara, L. Indriatmoko. 2012. Pigmen alami kaya manfaat. Food Review Indonesia 7:34-39.

Pervaiz, T., J. Songtao, F. Faghihi, M.S. Haider, J. Fang. 2017. Naturally occurring anthocyanin, structure, functions and biosynthetic pathway in fruit plants. J. Plant Biochem. Physiol. 5:187.

Putri, F.D., Sobir, M. Syukur, A. Maharijaya. 2017. Pengembangan kriteria seleksi untuk perakitan terung (Solanum melongana L.) berdaya hasil tinggi. J. Agron. Indonesia 45:182-187. 
Quaye, W., K. Adofo, Y.E. Madode, A.R. Abizari. 2009. Exploratory and multidisciplinary survey of the cowpea network in Tolon-Kumbungu district of Ghana: a food sovereignty perspective. Afr. J. Agric. Res. 4:311-320.

Qudah, J.M.E. 2014. Contents of chlorophyll and carotenoid pigments in common thyme (Thymus vulgaris L.). World Appl. Sci. J. 29:1277-1281.

Rios, S.A., M.C.D. Paes, W.S. Cardoso, A. Borem, F.F. Teixeira. 2014. Color of corn grains and carotenoid profile of importance for human health. American J. of Plant Sci. 5:857-862.

Sangeetha, R.K., V. Baskaran. 2010. Carotenoid composition and retinol equivalent in plants of nutritional and medicinal importance. Efficacy of $\beta$ carotene from Chenopodium album in retinol-deficient rats. Food Chem. 119:1584-1590.
Safawo, T., N. Senthil, M. Raveendran, S. Vellaikumar, K.N. Ganesan, G. Nallathambi, S. Saranya, V.G. Shobhana, B. Abirami, E.V. Gowri. 2010. Exploitation of natural variability in maize for $\beta$-carotene content using HPLC and gene specific markers. Electronic J. Plant Breed. 1:548-555.

Sims, D.A., J.A. Gamon. 2002. Relationships between leaf pigment content and spectral reflectance across a wide range of species, leaf structures and developmental stages. Remote Sens. Environ. 81:337-354.

Subuluntika, N., F. Ayustaningwarno. 2013. Kadar $\beta$-karoten, antosianin, isoflavon, dan aktivitas antioksidan pada snack bar ubi jalar kedelai hitam sebagai alternatif makanan selingan penderita diabetes melitus tipe 2 . J. Nutrition College 2:689-695. 